\title{
Gas6 Delays Senescence in Vascular Smooth Muscle Cells through the PI3K/ Akt/FoxO Signaling Pathway
}

\author{
Cheng-wei Jin ${ }^{a}$ Hui Wang ${ }^{a}$ Yan-qing Chen ${ }^{a}$ Meng-xiong Tang ${ }^{b}$ Guan-qi Fan ${ }^{a}$ \\ Zhi-hao Wang ${ }^{c}$ Li Li $^{a}$ Yun Zhanga Wei Zhanga Ming Zhonga \\ aKey Laboratory of Cardiovascular Remodeling and Function Research, Chinese Ministry of Education \\ and Chinese Ministry of Health, Department of Cardiology, Qilu Hospital of Shandong University, \\ Ji'nan, 'bepartment of Emergency, Qilu Hospital of Shandong University, Ji'nan, 'Department of \\ Geriatrics Medicine, Qilu Hospital of Shandong University, Ji'nan, P.R. China
}

\section{Key Words}

Gas6 • Growth arrest specific protein $6 \cdot \mathrm{Axl} \cdot$ Cellular senescence $\bullet$ Cell cycle arrest

\begin{abstract}
Background/Aims: Growth arrest-specific protein 6 (Gas6) is a cytokine that can be synthesized by a variety of cell types and secreted into the extracellular matrix. Previous studies have confirmed that Gas6 is involved in certain pathophysiological processes of the cardiovascular system through binding to its receptor, Axl. In the present study, we investigated the role of Gas6 in cellular senescence and explored the mechanisms underlying its activity. Methods: We used vascular smooth muscle cells (VSMCs) to create two cellular senescence models, one for replicative senescence (RS) and one for induced senescence (IS), to test the hypothesis that Gas6 delays senescence. Results: Gas6-treated cells appear relatively younger compared with non-Gas6-treated cells. In particular, Gas6-treated cells displayed decreased staining for SA- $\beta$-Gal, fewer G1 phase cells, and decreased levels of p16 $6^{\text {INK4a }}$ and p21 $1^{\text {Cip1 }}$ expression; conversely, Gas6-treated cells displayed more S phase cells and significantly increased proliferation indexes. Furthermore, in both the IS and RS models with Gas6 treatment, the levels of PI3K, p-Akt, and p-FoxO3a decreased following Axl inhibition by R428; similarly, the levels of $\mathrm{p}-\mathrm{Akt}$ and $\mathrm{p}$-FoxO3a also decreased following PI3K inhibition by LY294002. Conclusion: Gas6/Axl signaling is essential for delaying the cellular senescence process regulated by the PI3K/Akt/FoxO signaling pathway.
\end{abstract}

Ming Zhong

KARGER 125
Department of Cardiology, Qilu Hospital of Shandong University, No.107, Wen Hua Xi Road, Ji'nan, 250012, P.R. (China)

Tel. +86 5318216 9339, Fax +86 5318616 9356, E-Mail zhongmingzm@gmail.com 


\section{Cellular Physiology and Biochemistry}

Cell Physiol Biochem 2015;35:1151-1166

Jin et al.: Gas6 Delays the Senescence Process in VSMCs

\section{Introduction}

Aging is a phenomenon in which the functions, adaptability and resistance of an organism decrease over time [1]. With the global population aging at an accelerating pace, aging is becoming a primary focus of researchers worldwide. Accordingly, delaying many of the negative aspects of aging is vitally important for improving the human lifespan and quality of life. The aging of multiple organs can ultimately lead to diseases or even death, and the cardiovascular system is no exception [2-5]. Indeed, aging is one of the primary risk factors for cardiovascular diseases [6] because aging can alter cardiovascular metabolism, resulting in metabolic disorders of the extracellular matrix, abnormal apoptosis and inflammation $[7,8]$. These processes can affect the structure and function of the cardiovascular system, eventually leading to cardiovascular remodeling. The primary consequence of aging in blood vessels is a decrease in compliance and an increase in stiffness $[9,10]$.

In general, aging is caused by cell senescence $[11,12]$. Cellular senescence, or the state of irreversible growth arrest, can be triggered by telomere shortening, the epigenetic derepression of the INK4a/ARF locus, and DNA damage, among others [11]. Vascular smooth muscle cells (VSMCs) are the primary cell type in the tunica media vasorum, and the status of these cells can influence the structure and the function of blood vessels. Therefore, VSMCs are the most important factor to consider when studying vascular remodeling, particularly vascular stiffness [13]. Due to the limited life spans of somatic cells, vascular cells eventually enter into a state of irreversible growth arrest $[14,15]$. During this process, the levels of negative regulators of the cell cycle, such as $\mathrm{p} 53 / \mathrm{p} 21$ and $\mathrm{p} 16$, gradually increase with the number of cell divisions [16-22], leading to the stagnation of the cell cycle and the activation of cellular senescence $[18,23]$, which contributes to aging at both the tissue and individual levels [24, 25].

Growth arrest-specific protein 6 (Gas6) is a member of the vitamin K-dependent protein family and is encoded by growth arrest-specific gene 6 , which was first discovered in NIH/3T3 cells under serum starvation [26]. The receptor for Gas6, Axl, was first discovered in primary human myeloid leukemia cells [27] and was later shown to be a receptor tyrosine kinase [28]. Recent studies have shown that Gas6 can also activate two other receptors: Mer and Tyro3 (also called Sky). Although all three of these receptors are members of the TAM receptor family, their binding strengths with Gas6 and their biological effects are quite different [29]. Multiple studies have confirmed that the primary biological function of Gas6 binding to Axl is to prevent cells from undergoing apoptosis [30]. In addition, Gas6 and Axl play roles in the pathologies of vascular calcification [31], vascular remodeling and atherosclerosis [32]. Therefore, the pathophysiological processes in blood vessels and VSMCs are likely mediated by Gas 6 and Axl. Moreover, based on genetic polymorphism analyses, the gas 6 gene has been associated with stroke and acute coronary syndrome in humans [33-35].

Taken together, Gas 6 and Axl play critical roles in cardiovascular diseases by regulating the survival and migration of vascular cells and various functions of circulating blood cells. Furthermore, Gas6 and Axl are closely associated with vascular remodeling, particularly in VSMCs. However, the role of these molecules in the context of vascular aging and how they might affect vascular compliance and stiffness have not yet been addressed. In this study, we hypothesized that Gas6 and Axl might influence VSMC aging, thereby influencing the aging of blood vessels as a whole. Here we established two cellular senescence models by cell passaging serially and angiotensin II (Ang II) treatment, which were named the replicative senescence (RS) and the induced senescence (IS) respectively, in order to further tested this hypothesis and explored the signaling pathways downstream of Gas6/Axl that could provide insight regarding the specific mechanisms involved in this process. 


\section{Cellular Physiology and Biochemistry}

Cell Physiol Biochem 2015;35:1151-1166

\begin{tabular}{l|l}
\hline DOI: $10.1159 / 000373940$ & (C) 2015 S. Karger AG, Basel
\end{tabular}

www.karger.com/cpb

Jin et al.: Gas6 Delays the Senescence Process in VSMCs

\section{Materials and Methods}

Reagents and Antibodies

Recombinant mouse Gas6 (Gas6) protein and the recombinant mouse Axl-Fc protein fragment (Axl-Fc) were purchased from R\&D Systems (St. Paul, MN, USA). R428 (BGB324) was purchased from Selleck (Houston, TX, USA). LY294002 was purchased from Merck (Darmstadt, Hessen, Germany). Type II collagenase and angiotensin II were purchased from Sigma-Aldrich (St. Louis, MO, USA). Small interfering RNAs (siRNAs) against FoxO3a and the negative control were purchased from GenePharma (Shanghai, China). Lipofectamine ${ }^{\mathrm{m}} 2000$ was purchased from Invitrogen (Carlsbad, CA, USA). A Cell Cycle Analysis Kit was purchased from Becton-Dickinson Biosciences (San Diego, CA, USA). A Cell-Light" EdU DNA Cell Proliferation Kit was purchased from RiboBio Technology (Guangzhou, Guangdong, China). DMEM/F12 culture medium, fetal bovine serum (FBS) and 0.25\% trypsin were purchased from Gibco (Grand Island, NY, USA). The anti-Akt, anti-p-Akt, and anti-PI3-kinase $\mathrm{p} 110 \alpha$ antibodies, as well as a SA- $\beta$-Gal Staining Kit, were purchased from Cell Signaling Technology (Beverly, MA, USA). Other antibodies referred to in this paper were purchased from Santa Cruz Biotechnology (Santa Cruz, CA, USA). All chemicals were of the highest purity grade.

\section{Cell culture}

Primary vascular smooth muscle cells (VSMCs) were extracted from the aortas of 8-10-weekold C57BL/6J wild-type mice purchased from Vital River, Inc. This study was approved by the Animal Management Rules of the Chinese Ministry of Health (Document No. 55, 2001) and the Institutional Animal Care and Use Committee of Shandong University. All animals were maintained with a regular diet and sleep schedule at the Key Laboratory of Cardiovascular Remodeling and Function Research in Qilu Hospital of Shandong University. The animals were anesthetized using a phenobarbital solution delivered via intraperitoneal injection and then sacrificed before experimentation. Briefly, the aortas were minced, and the VSMCs were prepared with type II collagenase. The tissues were digested in an enzyme solution for $60-90$ minutes at $37^{\circ} \mathrm{C}$, and the cell mass suspension was centrifuged at 1,000 rpm for $5 \mathrm{~min}$. The cells were resuspended in medium and then added to $25 \mathrm{~cm}$ cell culture flasks. The mouse vascular smooth muscle cell lines (MOVAS) were obtained from the American Type Culture Collection (ATCC). All cells were maintained in DMEM/F12 culture medium supplemented with 10\% FBS under 5\% CO2 and 95\% humidified air at $37^{\circ} \mathrm{C}$. Then, the cells were used for western blotting analysis, flow cytometry and cell proliferation experiments.

\section{Establishment and identification of cell senescence models}

Primary VSMCs were serially passaged ten times to create a replicative senescence (RS) model. The cells passaged four times and treated with angiotensin II (Ang II) were used as an induced senescence (IS) model. Finally, we used SA- $\beta$-gal staining and quantified the levels of p21 ${ }^{\mathrm{Cip} 1}$ and $\mathrm{p} 16^{\mathrm{INK} 4 \mathrm{a}}$ protein expression by western blotting analysis to determine the degree of cell senescence.

\section{Western blotting analysis}

To extract protein, cells were harvested, washed with pre-cooled PBS solution three times for 5 min and then treated with cell lysis buffer (50 mM Tris, pH 7.4, $150 \mathrm{mM} \mathrm{NaCl}, 1 \%$ sodium deoxycholate, $0.1 \%$ SDS, and 1\% Triton X-100) containing protease inhibitor cocktail (Roche, Basel, Switzerland). Then, the cell lysates were centrifuged at $15,000 \mathrm{~g}$ for $10 \mathrm{~min}$ at $4^{\circ} \mathrm{C}$. Protein concentrations were determined using a Thermo BCA protein assay kit (Pittsburgh PA, Pennsylvania, USA), and the protein samples were prepared by mixing 1 volume of the supernatants with $1 / 4$ volume of the loading buffer, as previously described. Equal protein loading was verified by western blotting to detect GAPDH. The samples were separated on $10 \%$ SDS-polyacrylamide gels and then electrophoretically transferred to poly-vinylidene difluoride membranes. After incubation in blocking solution ( $5 \%$ non-fat milk) for $1.5 \mathrm{~h}$, the membranes were incubated with primary antibodies diluted in blocking solution for $12-16 \mathrm{~h}$ at $4^{\circ} \mathrm{C}$. Then, the membranes were washed with $1 \times$ TBST solution and treated with horseradish peroxidase-conjugated secondary antibodies for $1 \mathrm{~h}$. Next, the membranes were treated with ECL solution (Millipore, Darmstadt, Germany) according to the manufacturer's instructions and then imaged using an ImageQuant ${ }^{\mathrm{m}} \mathrm{LAS} 4000$ imager (GE, CT, USA). The mean gray values of each protein band were measured by Photoshop CS5 software (Adobe, San José, CA, 


\section{Cellular Physiology and Biochemistry}

Cell Physiol Biochem 2015;35:1151-1166

Jin et al.: Gas6 Delays the Senescence Process in VSMCs

USA). Relative band intensity was the ratio of gray value of interest protein to that of corresponding GAPDH. As for the phosphorylated proteins, relative band intensity was the ratio of gray value of phosphorylated protein to that of total protein.

\section{Senescence-associated $\beta$-galactosidase staining}

First, each group of cells was plated in 6-well plates. Then, the cells were washed with pre-cooled PBS solution three times for $5 \mathrm{~min}$ on a decolorization table and then fixed with a $4 \%$ paraformaldehyde solution for $15 \mathrm{~min}$ at room temperature. All samples were treated as described in the instructions for the SA- $\beta$-Gal Staining Kit. The cells were incubated at $37^{\circ} \mathrm{C}$ without $\mathrm{CO}_{2}$ to maintain a $\mathrm{pH}$ of 6.0 . For each group, three fields of cells were selected randomly and photographed using an inverted phase contrast microscope (Olympus, Tokyo, Japan). Cells had blue-green granules in their cytoplasm were regarded as positive stained of SA- $\beta$-gal and we used Image-Pro Plus 6.0 software (Bethesda, MD, USA) to calculated the positive staining of cells accounted for the proportion of all cells in the same field of view.

\section{Cell cycle analysis by flow cytometry}

Cells $\left(1 \times 10^{4}\right)$ were treated with $0.25 \%$ trypsin, centrifuged at $1,000 \mathrm{~g}$ for $5 \mathrm{~min}$ at $4^{\circ} \mathrm{C}$, washed, and resuspended in pre-cooled PBS solution. Then, the fixed cells were incubated in 70\% ethanol for $12-24 \mathrm{~h}$ at $4^{\circ} \mathrm{C}$. The next day, the cells were pelleted, treated with $100 \mathrm{~mL}$ RNase $(0.2 \mathrm{mg} / \mathrm{mL}$ in PBS) for $5 \mathrm{~min}$ at room temperature and then resuspended in $1 \mathrm{~mL} \mathrm{ddH_{2 }} 0$. After staining with $4 \mathrm{mg} / \mathrm{mL}$ of propidium iodide, the DNA content was determined using a Becton Dickson LSRII Flow Cytometer System with FACSDiva software, and the cell cycle profile was analyzed using ModFit LT 3.2 software (Verity Software House, Topsham, USA).

\section{Proliferation assay}

We used 5-ethynil-2'-deoxyuridine (EdU), which is an analog of thymidine, to detect the proliferation levels of the cells. First, the cells were plated in 24-well plates, treated with complete medium containing $50 \mu \mathrm{M}$ EdU staining solution, and incubated for $2 \mathrm{~h}$. All procedures were performed according to the instructions provided in the EdU DNA Cell Proliferation Kit. Laser-scanning confocal microscopy (Carl Zeiss Jena, Oberkochen, Germany) and the Carl Zeiss ZEN software system were used to collect images. For each group, three fields of cells were randomly selected, and the cell proliferation level was analyzed using Image-Pro Plus 6.0 software (Bethesda, MD, USA).

\section{siRNA-mediated knockdown experiments}

A Fox03a (5'-GGAGUUUGGUCAAUCAGAAATT-3') oligoribonucleotide siRNA was used to inhibit FoxO3a expression, and a scrambled control siRNA (5'-UUCUCCGAACGUGUCCGUTT-3') was used as a negative control (NC). Plasmids or oligoribonucleotides were transfected into cells grown in a six-well plate using Lipofectamine ${ }^{\text {tw }} 2000$ transfection according to the manufacturer's protocol. MOVAS cells were used for experimentation after $24-48 \mathrm{~h}$ of transfection.

\section{Statistical analysis}

The data are expressed as the mean \pm SD. SPSS 19.0 software (Chicago, IL, USA) was used for the statistical analyses. Differences between two groups were determined using independent samples, and Student's t-test and one-way ANOVA were used to compare the results among the groups. Statistical analyses were performed using the GraphPad Prism 5.01 software program (San Diego, CA, USA). Differences with $P$ values less than 0.05 were considered statistically significant. Comparisons that did not reach this significance threshold were not noted.

\section{Results}

The identification of cellular senescence models

When the primary VSMCs were passaged ten times, we found that the SA- $\beta$-gal (senescence-associated $\beta$-galactosidase) staining rate and the $\mathrm{p} 21^{\mathrm{Cip} 1}$ and $\mathrm{p} 16^{\mathrm{INK} 4 \mathrm{a}}$ expression levels significantly increased compared with earlier passages. Therefore, we used $10^{\text {th }}$. passage cells as a replicative senescence model (RS) (Fig. 1A and 1B). In addition, we also 


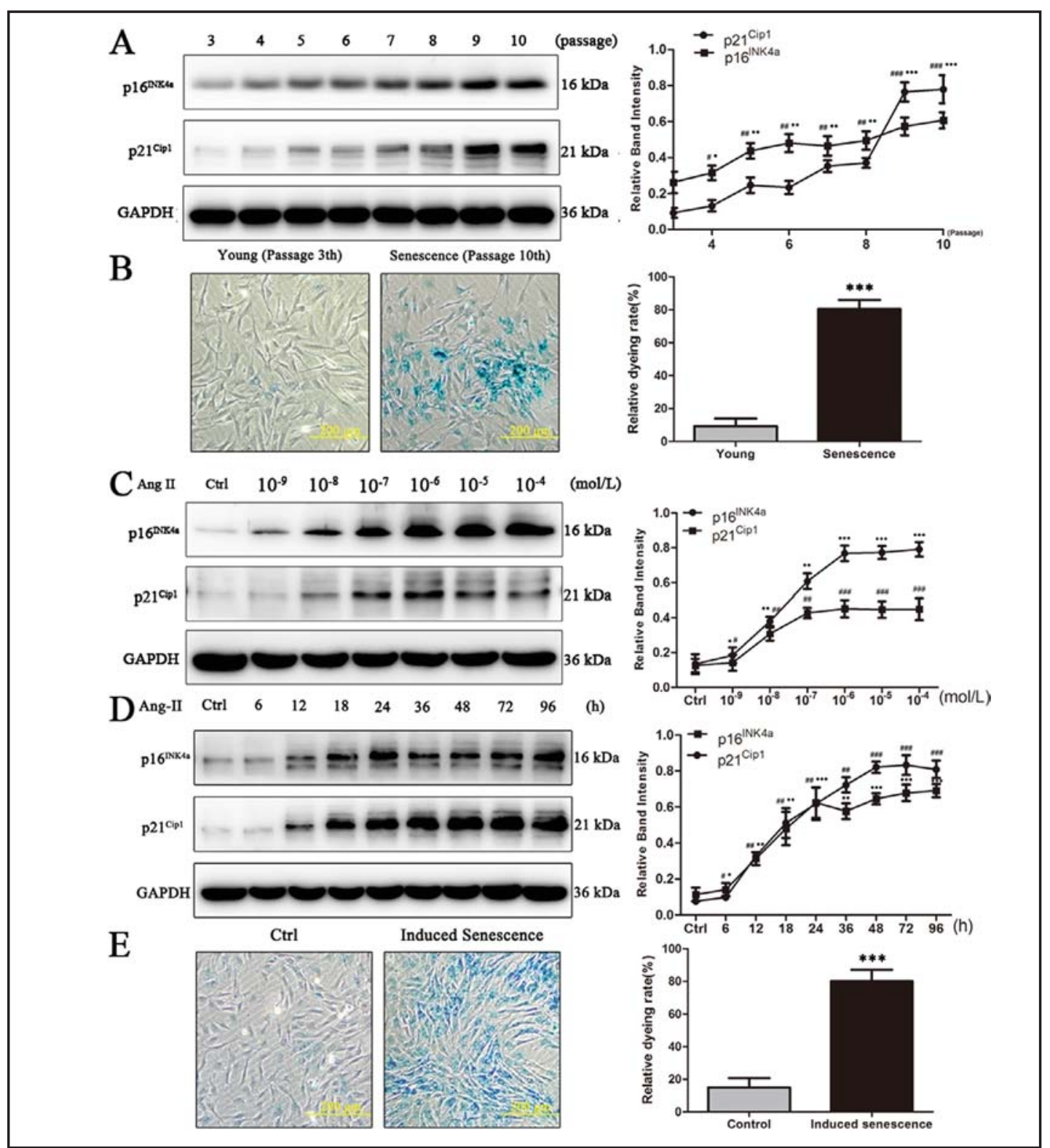

Fig. 1. Establishing and verifying the cellular senescence models. (A and B) Western blots and SA- $\beta$-gal stainings demonstrating that cells passaged ten times could serve as a model for replicative senescence (RS) (C, D and E) and that cells passaged four times and treated with Ang II $\left(1 \times 10^{-6} \mathrm{~mol} / \mathrm{L}\right)$ for $48 \mathrm{~h}$ could serve as a model for induced senescence (IS). All the results shown are from representative experiments $(\mathrm{n}=3$ in each case). The values are presented as the mean \pm SD. ${ }^{*} P<0.05,{ }^{* *} P<0.01$ and ${ }^{* * *} P<0.001$ compared with the control; ${ }^{\#} P<0.05$, ${ }^{\#} P<0.01$ and ${ }^{\# \# ~} P<0.001$ compared with the control. Bar, $200 \mu \mathrm{m}$.

established an induced senescence model (IS). In particular, we found that cells passaged four times could become senescent when treated with Ang II for $48 \mathrm{~h}$ at a concentration of $1 \times 10^{-6}$ $\mathrm{mol} / \mathrm{L}$, as determined by the $\mathrm{p} 21^{\mathrm{Cip} 1}$ and $\mathrm{p} 16^{\mathrm{INK} 4 \mathrm{a}}$ expression levels; the SA- $\beta$-gal staining rate was also significantly increased by this treatment (Fig. 1C, 1D and 1E). Therefore, we believe that RS and IS models can be established using the above-described methods.

Gas6 is involved in the VSMC senescence process

When the cells were treated with Gas 6 at a concentration of $250 \mathrm{ng} / \mathrm{mL}$ for $36 \mathrm{~h}$ (with additional Gas 6 added every $12 \mathrm{~h}$ ), the $\mathrm{p} 21^{\text {Cip } 1}$ and p $16^{\text {INK4a }}$ expression levels significantly 


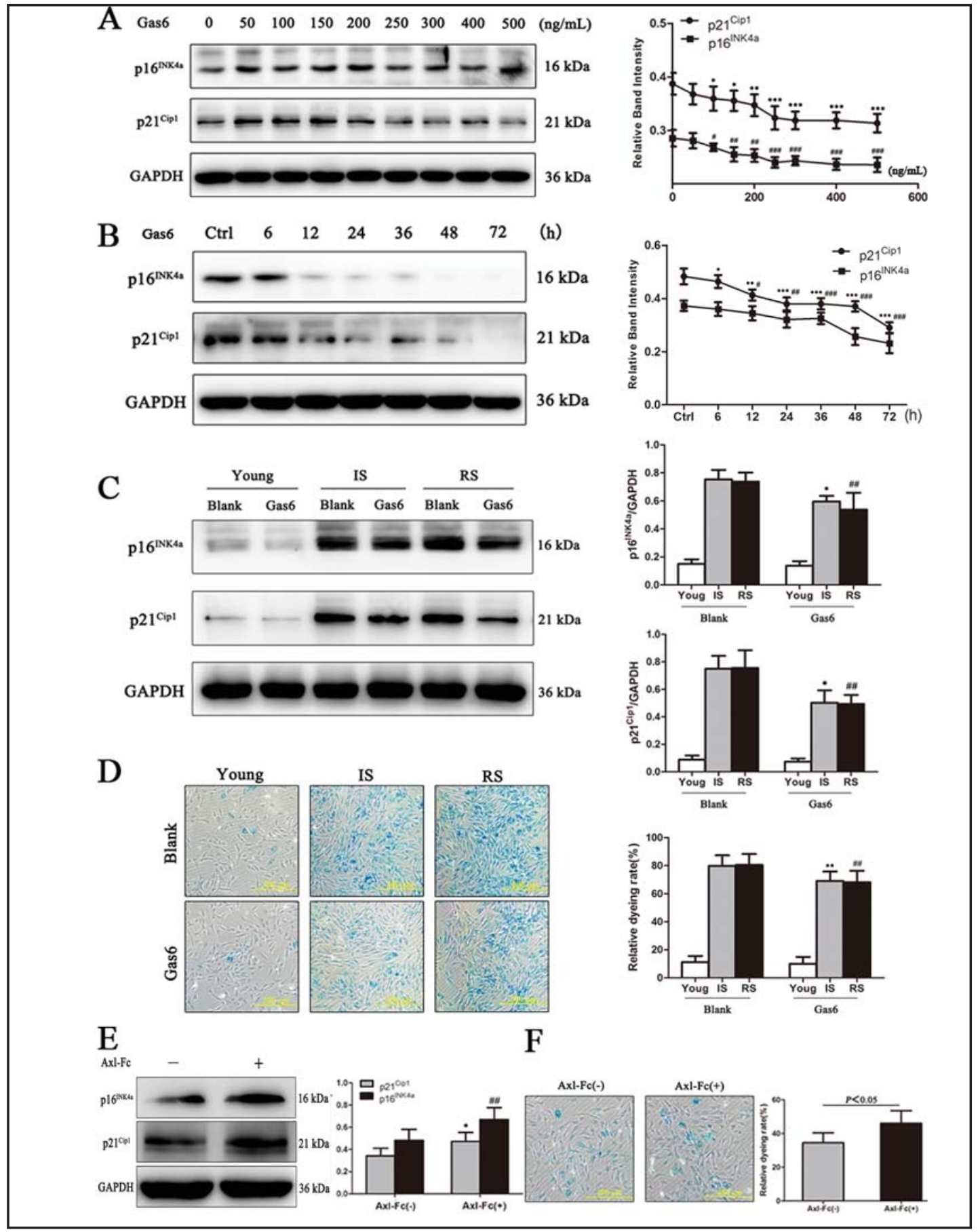

Fig. 2. Gas6 delays the senescence process in VSMCs. (A and B) Western blots demonstrating that cells treated with Gas6 $(250 \mathrm{ng} / \mathrm{mL})$ for $36 \mathrm{~h}$ have significantly decreased p16 $16^{\text {INK4a }}$ and p21 $1^{\text {Cip } 1}$ expression. (C) The effects of Gas6 on the IS and RS models were examined using western blotting. In the IS model, the Gas6-treated cells showed low p $21^{\text {Cip } 1}$ and $\mathrm{p} 16^{\text {INK4a }}$ expression. In the RS model, the Gas6-treated cells also showed low $\mathrm{p} 21^{\text {Cip } 1}$ and $\mathrm{p} 16^{\mathrm{INK} 4 \mathrm{a}}$ expression. (D) The results of SA- $\beta$-Gal stainings showed that the Gas6-treated cells showed significantly less staining than their corresponding non-Gas6-treated cells in both the IS and the RS models. (E and F) When these cells were treated with Axl-Fc, the levels of p16 $6^{\text {INK4a }}$ and p21 $1^{\text {Cip } 1}$ and the staining rate of SA- $\beta$-Gal significantly increased. All the results shown are from representative experiments ( $n=3$ in each case). The values are presented as the mean \pm SD. ${ }^{*} P<0.05,{ }^{* *} P<0.01$ and ${ }^{* * *} P<0.001$ compared with the corresponding blank group; ${ }^{\#} P<0.05$, ${ }^{\# \#} P<0.01$ and ${ }^{\# \#} P<0.001$ compared with the corresponding blank group. Bar, $200 \mu \mathrm{m}$. 


\section{Cellular Physiology and Biochemistry}

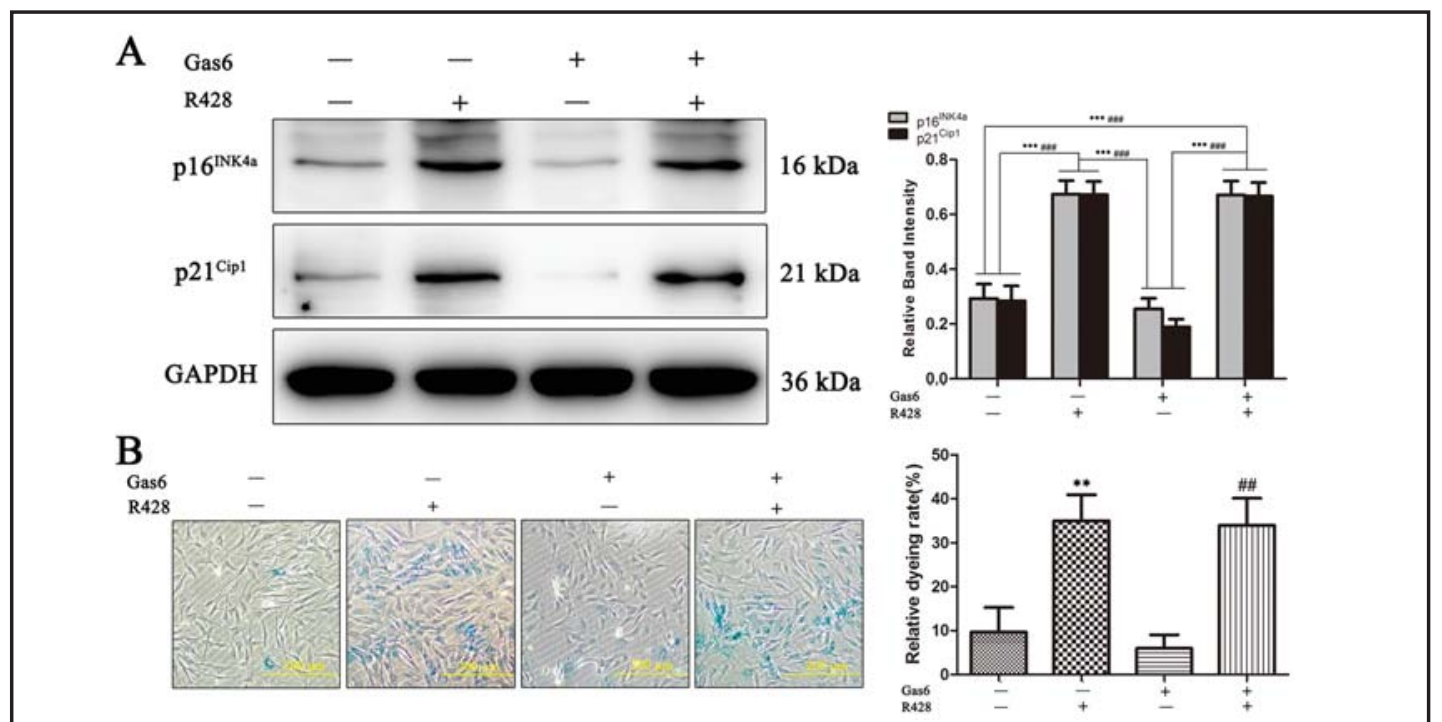

Fig. 3. Axl is the primary receptor in the Gas6-mediated anti-senescence effect. (A) Western blotting and SA$\beta$-gal staining demonstrated that the levels of $\mathrm{p} 16^{\mathrm{INK4a}}$ and $\mathrm{p} 21^{\mathrm{Cip} 1}$ protein expression significantly increased in R428-treated cells regardless of Gas6 treatment compared with the two R428-free cell groups, whereas no significant difference was observed between the two R428-treated cell groups. (B) The SA- $\beta$-Gal staining results showed that the positive staining rates in the two R428-treated cell groups increased significantly compared with the two R428-free cell groups. All the results shown are from representative experiments ( $n=3$ in each case). The values are presented as the mean \pm SD. ${ }^{* *} P<0.01$ and ${ }^{* * *} P<0.001$ compared with the non-R428-treated group; ${ }^{\# \#} P<0.01$ and ${ }^{\# \# ~} P<0.001$ compared with the non-R428-treated group. Bar, $200 \mu \mathrm{m}$.

decreased compared with those of the controls (Fig. 2A and 2B). To study Gas6 in the context of cellular senescence, we also treated the RS and IS models with $250 \mathrm{ng} / \mathrm{mL}$ Gas 6 for $36 \mathrm{~h}$.

For the RS model, we treated $9^{\text {th }}$-passage cells with Gas6 for $36 \mathrm{~h}$ and then passaged them a tenth time because cellular senescence is an irreversible process. For the IS model, Gas6 was added 12 hours after the Ang II treatment, and then the cells were incubated with these two molecules for $48 \mathrm{~h}$. We obtained similar results with both models. In the IS model, the Gas6-treated cells displayed lower levels of p21 $1^{\mathrm{Cip} 1}$ and $\mathrm{p} 16^{\mathrm{INK} 4 \mathrm{a}}$ expression. In the RS model, the Gas6-treated cells also displayed lower levels of p21 ${ }^{\mathrm{Cip} 1}$ and $\mathrm{p} 16^{\mathrm{INK} 4 \mathrm{a}}$ expression. In contrast, no significant differences were observed between young cells with and without Gas6 treatment (Fig. 2C). We also performed SA- $\beta$-Gal staining for each group, and the staining rates in Gas6-treated cells in both the IS and RS models were significantly lower than in the corresponding non-Gas6-treated cells. However, no significant differences were observed between young cells with and without Gas6 treatment (Fig. 2D).

To investigate whether the anti-senescent effects of Gas6 are mediated by Axl, we used a soluble form of Axl, the Axl-Fc protein, to neutralize Gas6 within the supernatant at a dilution of $10 \mu \mathrm{g} / \mathrm{mL}$ for $36 \mathrm{~h}$. The results showed that the protein expression levels of $\mathrm{p} 16^{\mathrm{INK} 4 \mathrm{a}}$ and $\mathrm{p} 21^{\mathrm{Cip} 1}$ and the staining rate of SA- $\beta$-Gal significantly increased in Axl-Fc-treated cells (Fig. 2E and 2F).

Taken together, these results demonstrate that Gas6 plays an anti-senescence role in VSMCs.

\section{Axl plays a key role in Gas6-mediated anti-senescence}

To explore whether Axl is the only receptor for Gas6 in this process, we used a specific inhibitor of Axl, R428, to block Gas6 activity. Cells were treated with R428 $(1 \mu \mathrm{M})$ and Gas6 $\left(250 \mathrm{ng} / \mathrm{mL}\right.$ ) every $12 \mathrm{~h}$ for $36 \mathrm{~h}$ total. The results indicated that the levels of p16 ${ }^{\text {INK4a }}$ and p2 $1^{\text {Cip1 }}$ protein expression significantly increased in cells treated with R428 compared with the other two groups of cells, regardless of whether Gas6 was added. However, no significant 


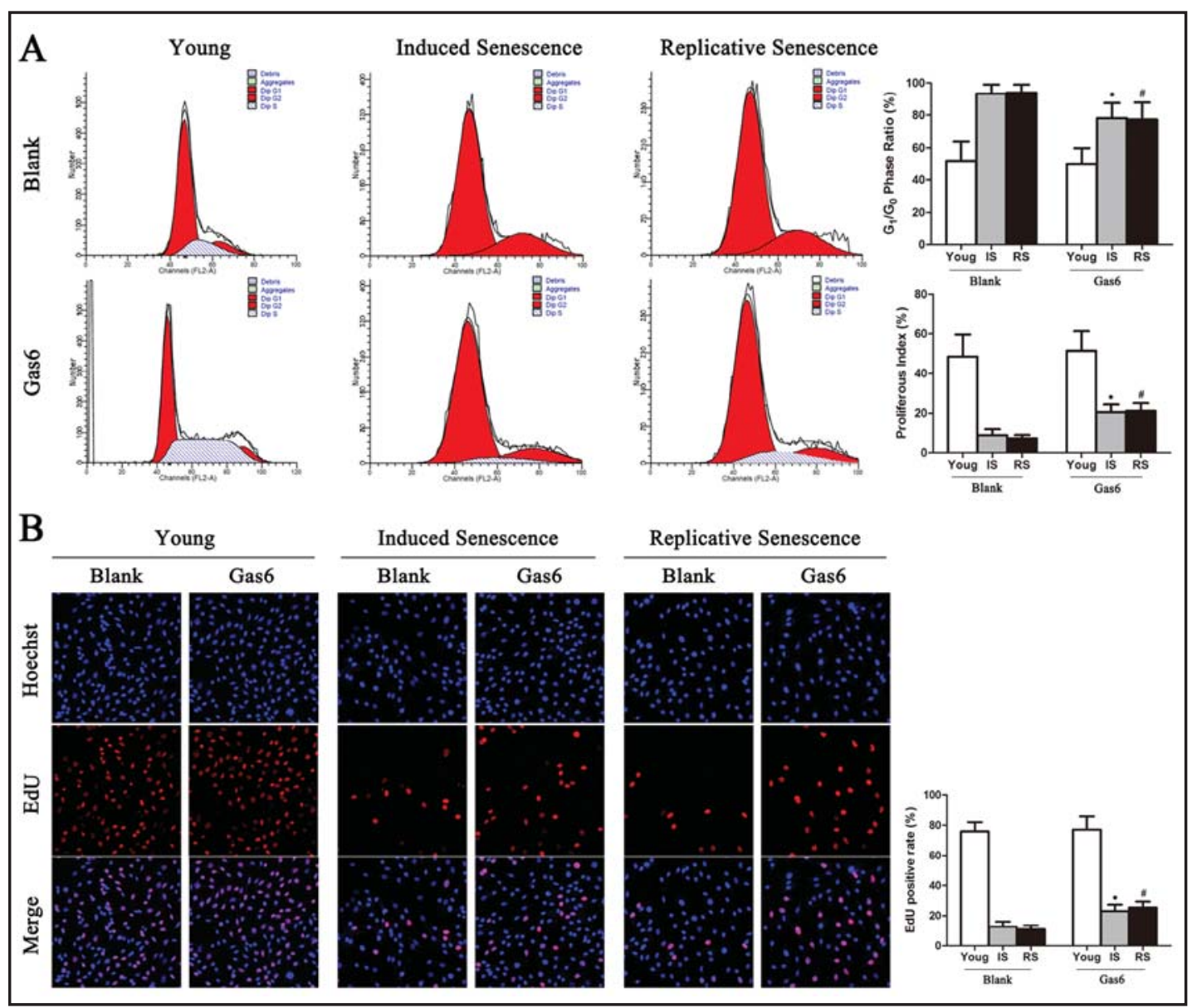

Fig. 4. Gas6 promotes the transition from G1 to $\mathrm{S}$ phase. Cell cycle analyses showing that Gas6-treated cells in both the IS and the RS models showed higher percentages of S phase and a lower percentage of G1 phase cells compared with non-Gas6-treated cells; the proliferation index (PI) significantly increased compared with the corresponding controls. (B) EdU staining results showed that the positive staining rates in both the IS and the RS models after Gas6 treatment were higher than in controls. All the results shown are from representative experiments $\left(\mathrm{n}=3\right.$ in each case). The values are presented as the mean $\pm \mathrm{SD}$. ${ }^{*} P<0.05$ compared with the non-Gas6-treated group; ${ }^{\#} P<0.05$ compared with the non-Gas6-treated group.

difference was observed between the two R428-treated groups (Fig. 3A). The results of the SA- $\beta$-Gal staining experiments were similar to the results described above. We also noted that as long as the cells were treated with R428, their staining rate increased significantly compared with non-R428-treated cells. Additionally, no significant differences were observed between R428-treated cells (Fig. 3B). These results indicate that Axl is the primary receptor of Gas6 in the cellular senescence process.

\section{Gas6-treated cells transition from G1 to $S$ phase}

Next, we performed experiments to investigate the effects of Gas6 on the cell cycle distribution of senescent cells. In the IS model, the Gas6-treated cells displayed a higher percentage of S phase cells and a lower percentage of G1 phase cells compared with the control; similar results were observed for the RS model. By contrast, in young cells, the percentages of S phase and G2 phase cells increased after Gas6 treatment (Fig. 4A). Moreover, Gas6-treated cells displayed higher proliferation, with the proliferation index [PI, $\mathrm{PI}=(\mathrm{S}+\mathrm{G} 2 / \mathrm{M}) /(\mathrm{G} 1+\mathrm{S}+\mathrm{G} 2 / \mathrm{M})]$ increasing significantly compared with non-Gas6-treated cells. These findings suggest that Gas6 can reduce the ratio of cell cycle-arrested cells, promote the transition of cells from G1 to S phase, and increase cell proliferation activity. 


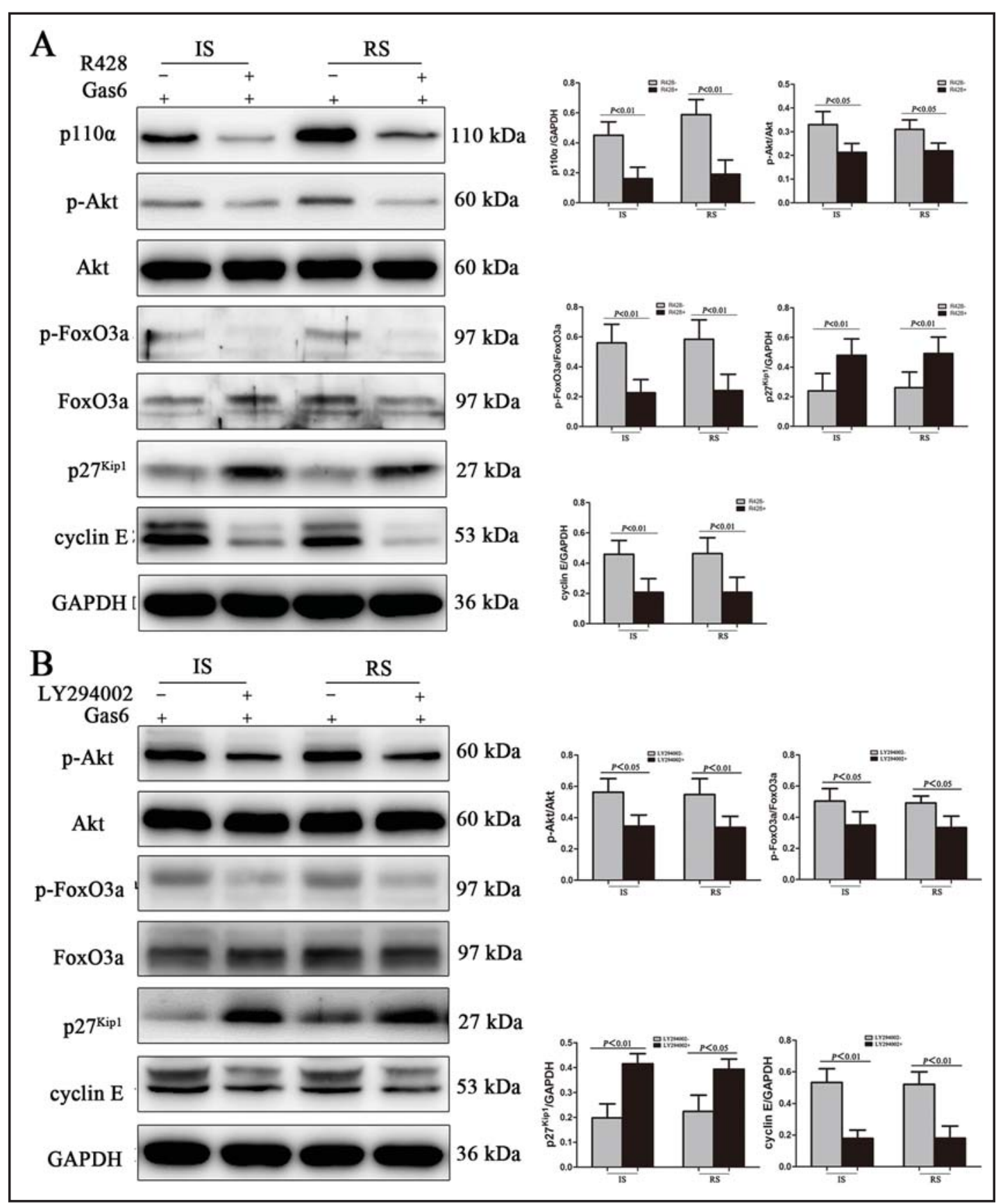

Fig. 5. The PI3K/Akt/FoxO3a signaling pathway is involved in the senescence process. (A) Western blotting results showing that the levels of $\mathrm{p} 110 \alpha$ (PI3K), p-Akt, p-FoxO3a and cyclin E in both the IS and RS models decreased following the blockage of Axl by R428, whereas the levels of $\mathrm{p} 27^{\mathrm{Kip} 1}$ increased compared with the corresponding non-R428-treated group. (B) Western blotting results showing that blocking PI3K with LY294002 in both the IS and RS models caused p-Akt, p-FoxO3a and cyclin E levels to decrease and p27 $7^{\text {Kip1 }}$ levels to increase compared with the corresponding non-LY294002-treated group. All the results shown are from representative experiments ( $\mathrm{n}=3$ in each case). The statistical results are indicated above the histograms.

In addition, we used EdU (5-ethynil-2'-deoxyuridine) staining to further verify the cell proliferation activity in each group. In the IS model, the positive rate of EdU staining following Gas6 treatment increased compared with the controls. In the RS model, Gas6-treated cells also displayed a higher proportion of EdU-positive cells compared with the controls. By 


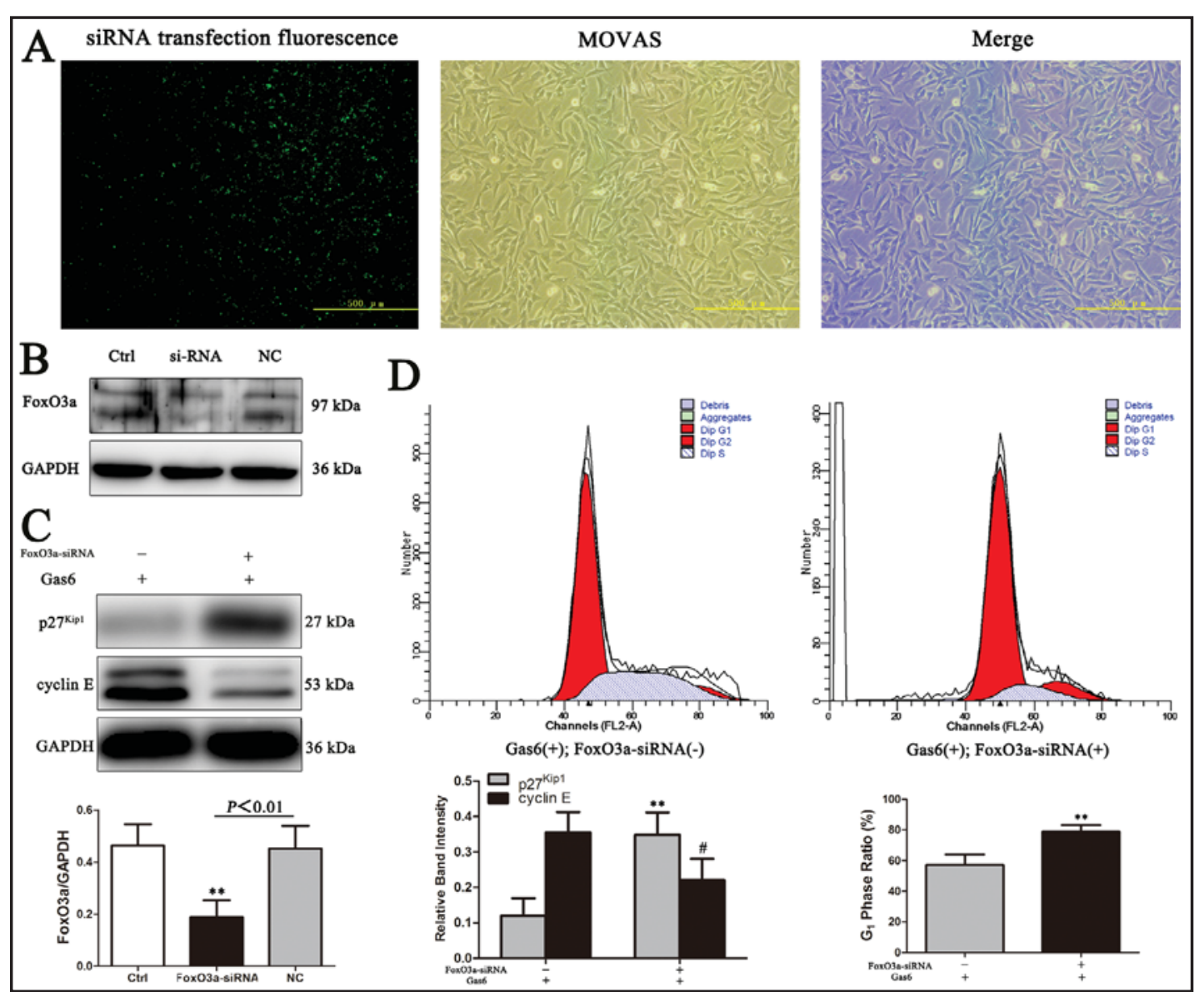

Fig. 6. FoxO is the key factor in this Gas6-mediated cellular senescence process. (A) The transfection efficacy of the FoxO3a siRNA plasmid. (B) The test of the silencing efficacy of the FoxO3a siRNA by western blotting. (C) Cyclin E expression was reduced, whereas p27 $7^{\mathrm{Kip} 1}$ expression was increased at $48 \mathrm{~h}$ following FoxO3a inhibition. (D) The results from the cell cycle analysis using flow cytometry showing that the percentage of G1 phase cells increased and the percentage of S phase cells decreased at 48 following FoxO3a inhibition. All the results shown are from representative experiments ( $n=3$ in each case). The values are presented as the mean \pm SD. ${ }^{* *} P<0.01$ compared with the corresponding control groups; ${ }^{\#} P<0.05$ compared with the corresponding control group. Bar, $500 \mu \mathrm{m}$.

contrast, no statistically significant differences were observed between young cells with and without Gas6 treatment (Fig. 4B).

Therefore, we conclude that Gas6 can decrease the percentage of cells in G1 phase, thereby promoting cell proliferation activity.

Gas6/Axl mediate cellular senescence through the PI3K/Akt/FoxO3a signaling pathway

To explore the signaling pathways downstream of Gas6 and Axl that delay senescence processes in VSMCs, cells were serum-starved for $12 \mathrm{~h}$ to synchronize the cell cycle. Next, we blocked Axl using R428. The R428+Gas6-treated cells were treated with R428 (1 $\mu \mathrm{M})$ for $1 \mathrm{~h}$ in advance to block Axl and then treated with Gas6 (250 ng/mL) for $1 \mathrm{~h}$. Non-R428treated cells were treated with Gas 6 alone for $1 \mathrm{~h}$. In the IS model, compared with nonR428-treated cells, R428-treated cells displayed lower expression levels for $\mathrm{p} 110 \alpha$ (PI3K), p-Akt, p-FoxO3a and cyclin E, whereas the levels of p $27^{\text {Kip } 1}$ increased significantly. Similar results were observed in the RS model, with PI3K, p-Akt, p-FoxO3a and cyclin E displaying decreased expression and with p27 $7^{\mathrm{Kip} 1}$ displaying increased expression following R248 treatment compared with non-R428-treated cells (Fig. 5A). 


\section{Cellular Physiology and Biochemistry}

Cell Physiol Biochem 2015;35:1151-1166

Jin et al.: Gas6 Delays the Senescence Process in VSMCs

Next, we blocked PI3K activity using LY294002. LY294002+Gas6-treated cells were treated with LY294002 $(10 \mu \mathrm{M})$ for $1 \mathrm{~h}$ in advance to block PI3K, and then the cells were treated with Gas6 (250 ng/mL) for $1 \mathrm{~h}$. For the IS model, compared with non-R428-treated cells, the R428-treated cells displayed lower levels of p-Akt, p-FoxO3a and cyclin E expression, whereas p27Kip1 expression significantly increased. Similar results were observed for the RS model: p-Akt, p-FoxO3a and cyclin E levels decreased, and p27Kip1 levels increased (Fig. 5B).

In summary, these results indicate that the PI3K/Akt/FoxO signaling pathway is involved in this senescence process.

FoxO plays a key role in senescence

To explore the effects of FoxO in this process, we inhibited Fox03a expression using a FoxO3a-specific siRNA. The transfection efficacy of the FoxO3a siRNA into MOVAS cells was approximately $80 \%$ (Fig. 6A). We also tested the protein expression levels of FoxO3a to verify the silencing efficiency, and we found that the Fox03a expression levels significantly decreased following transfection with the FoxO3a siRNA for $24 \mathrm{~h}$ (Fig. 6B). Next, we tested the signaling molecules downstream of FoxO3a after siRNA treatment. Compared with the cells treated with Gas 6 alone, the cells treated with Gas6 and FoxO siRNA together for 48 $\mathrm{h}$ displayed significantly increased $\mathrm{p} 27^{\mathrm{Kip} 1}$ protein expression and significantly decreased cyclin E expression (Fig. 6C). Moreover, the cell cycle analysis revealed that, compared with the cells treated with Gas6 alone, the cells treated with both Gas6 and Fox03a siRNA displayed more G1 phase cells and fewer S phase cells (Fig. 6D).

Considering the above results, we conclude that FoxO is the key factor in this pathway and the primary target of Gas6 in mediating senescence in VSMCs.

\section{Discussion}

In this study, we demonstrated that Gas6 treatment could delay cellular senescence and that cellular senescence levels increase following the inhibition of the Gas6 receptor Axl using the Axl-specific inhibitor R428. We showed that Gas6 and Axl are associated with cell cycle arrest, which is an important trigger in the development of cellular senescence. In addition, we demonstrated that Gas 6 could promote the G1/S phase transition and rescue cells from cell cycle arrest. Finally, we showed that these effects are mediated by the activation of the PI3K/Akt/FoxO signaling pathway.

Although numerous factors can lead to cellular senescence, telomere-dependent senescence and stress-induced premature senescence (SIPS) are currently considered the two most important factors in this process [36, 37]. Hayflick et al. found that somatic cells are not capable of unlimited proliferation in vitro and will eventually stop growing and dividing, which is a phenomenon known as the "Hayflick limit" [38]. Therefore, we established a replicative senescence model by passaging cells serially to simulate the natural aging process in vivo. We also established an induced senescence model using Ang II treatment to simulate stress-induced senescence because the formation of superoxide anions can be induced by Ang II and activate NADPH oxidase [39, 40]. Intracellular reactive oxygen species (ROS) levels can be increased by superoxide anion, and ROS can stimulate the cellular senescence process. Indeed, Ang II has been previously shown to cause premature senescence in VSMCs [41, 42]. Therefore, we chose Ang II to induce cellular senescence in this experiment.

Cellular senescence primarily involves two important signaling pathways: the $\mathrm{p} 16^{\mathrm{INK} 4 \mathrm{a}} / \mathrm{Rb}$ pathway and the $\mathrm{p} 53 / \mathrm{p} 21$ pathway $[20,43-45]$. The expression levels of p16 and p21, two important cyclin-dependent kinase inhibitors (CDKIs), significantly increase in senescent cells [20]. Therefore, we chose $\mathrm{p} 21^{\mathrm{Cip} 1}$ and $\mathrm{p} 16^{\mathrm{INK} 4 \mathrm{a}}$ as two important markers for the identification of cellular senescence. SA- $\beta$-Gal staining was also used as an index to quantify the levels of cellular senescence [46]. 


\section{Cellular Physiology and Biochemistry}

Cell Physiol Biochem 2015;35:1151-1166

\begin{tabular}{l|l}
\hline DOI: $10.1159 / 000373940$ & (C) 2015 S. Karger AG, Basel
\end{tabular}

www.karger.com/cpb

Jin et al.: Gas6 Delays the Senescence Process in VSMCs

Gas 6 can be synthesized and secreted by VSMCs into culture medium in vitro. Therefore, we treated cells with a soluble form of the Axl receptor Axl-Fc to neutralize Gas6 in the cell culture supernatant. In particular, Axl-Fc should compete with endogenous Axl for Gas6, thus reducing the effective levels of Gas6 in the medium, equivalent to reducing the levels of Gas6 in the extracellular matrix. We found that the senescence levels in Axl-Fc-treated cells were much higher than in controls. These findings show that Gas6 levels positively correlate with cell senescence and confirm that Gas6 can delay the cell senescence process.

Gas6 can bind to three types of receptors with extremely different biological functions [29]. Strong evidence indicates that Axl plays an important role in the vascular system, particularly in vascular remodeling and angiogenesis [47-50]. Arguably, Axl is more closely related to the pathological and physiological processes of vascellum. Therefore, we used a specific inhibitor of Axl, R428 [51], to explore the changes in the cellular senescence process. We found that R428-treated cells, regardless of whether these cells were also treated with Gas6, showed higher senescence levels compared with non-R428-treated cells; no significant differences were observed between these two R428 treatment groups. Therefore, we propose that Axl is the primary receptor involved in Gas6-mediated cellular senescence delays.

Cell cycle arrest is the most important factor for determining the fate of cells [52], and long-term stagnation with irreversible cell cycle arrest marks the beginning of senescence [53]. Indeed, the primary identifier of cellular senescence is an increase in the proportion of G1/G0 phase cells relative to $S$ phase cells. Therefore, rescuing early senescent cells from cell cycle arrest is key to delaying cellular senescence. In this study, we found that Gas 6 can promote the transition of cells from G1/G0 phase to S phase, suggesting that Gas 6 could delay the senescence process in VSMCs.

We also found that Gas6 can activate the PI3K/Akt pathway following binding to its receptor Axl, which was observed in both the IS and RS models; in particular, the R428-treated cells showed low levels of p110 $\alpha$ (the catalytic subunit of PI3K [54]) and p-Akt compared with the control cells. As a downstream effector of Akt, FoxO can be phosphorylated by p-Akt [55]. Moreover, FoxO specifically binds to 14-3-3 chaperones, leading to conformational changes that expose a nuclear export signal (NES) and that mask a nuclear localization signal (NLS). This binding results in the shuttling of FoxO from the nucleus into the cytoplasm, preventing the transactivation of responsive genes such as $p 27$ [56].

p27 ${ }^{\mathrm{Kip} 1}$, which is a broad-spectrum CDKI $[57,58]$, is a downstream target of FoxO involved in cell cycle regulation [59]. Our results show that the levels of p-FoxO3a increase following Gas6 treatment, indicating a decrease in the transcriptional activity of FoxO. As one of the most important factors in regulating the G1/S phase transition, p27 $7^{\text {kip } 1}$ can prevent the conversion of cells from G1 phase to $S$ phase, resulting in cell cycle arrest [60, 61]. By contrast, as an antagonist of $\mathrm{p} 27^{\mathrm{Kip} 1}$, the CDK2/cyclin E complex is a positive factor that can promote G1/S transition [62]. In the present study, we found that Gas6-treated cells showed decreased levels of p27 ${ }^{\text {kip } 1}$ protein expression in both the IS and RS models compared with their respective controls. The opposite was found for cyclin E; the levels of cyclin E increased significantly in both the IS and RS models treated with Gas6. These results are consistent with those from the cell cycle analyses showing that Gas6-treated cells display a low percentage of G1 phase cells. Therefore, we can conclude that Gas6 promotes the G1/S phase transition, which is most likely achieved through the activation of the PI3K/Akt/FoxO signaling pathway.

Previous studies have shown that FoxO participates in cell cycle regulation [63, 64]; FoxO can block the cell cycle by regulating the levels of CDKs and CDKIs, such as cyclin D and $\mathrm{p} 27^{\mathrm{Kip} 1}[59,65]$. FoxO is also involved in the regulation of vascular homeostasis [66]. Therefore, FoxO plays a crucial and multifaceted role in vascular aging and angiosclerosis. In this study, we hypothesized that FoxO was involved in the senescence process affected by Gas6. To test this hypothesis, we silenced the expression of FoxO3a using a specific siRNA; we also used MOVAS cells for these experiments because the transfection efficacy in primary VSMCs is unsatisfactory. We found that cells treated with a FoxO siRNA had higher p2 $7^{\mathrm{Kip} 1}$ expression compared with controls, whereas cyclin E levels displayed the opposite 


\section{Cellular Physiology and Biochemistry}

Cell Physiol Biochem 2015;35:1151-1166

\begin{tabular}{l|l}
\hline DOI: $10.1159 / 000373940$ & (C) 2015 S. Karger AG, Basel
\end{tabular}

www.karger.com/cpb

trend. Using cell cycle analysis, we also found that the percentages of G1 phase cells and S phase cells increased and decreased, respectively, which may be because Gas6 can no longer regulate the balance between $\mathrm{p} 27^{\mathrm{Kip} 1}$ and cyclin E following the silencing of FoxO3a using siRNA. Considering the above results, we propose that Gas6 can promote the G1/S phase transition and rescue cells from cell cycle arrest and that FoxO is the key signaling factor in this process.

In summary, we discovered a novel role for Gas6 and Axl in VSMC senescence and identified the relevant signaling molecules involved in this process. However, the influence that Gas6/Axl may have on the senescence process in other vascular cells remains unclear. In addition, these results were obtained in vitro, and future studies will be required to determine whether the Gas6/Axl-PI3K/Akt/FoxO signaling pathway is involved in vivo. This study should provide new insights regarding vascular aging and angiosclerosis.

\section{Conclusions}

In this study, we demonstrate that Gas6 plays a role in cell cycle arrest, promotes the G1/S phase transition and alleviates senescence in VSMCs, with Axl playing a key role in this process. We demonstrate that these effects are mediated by the binding of Gas6 to its receptor Axl. The PI3K/Akt/FoxO signaling pathway appears to be the major target of Gas6/ Axl signaling in VSMC senescence, with FoxO being the key factor in this signaling pathway.

\section{Acknowledgments}

This work was supported by the research grants from the National Basic Research Program of China (973 Program, Grant No.2013CB530700), the National Natural Science Foundation of China (81070192, 81070141, 81100605, 81270352 and 81270287), the Natural Science Foundation of Shandong Province (BS2013YY017), the Independent Innovation Foundation of Shandong University (2012JC034) and cardiovascular exploration research foundation of Chinese Medical Doctor Association (DFCMDA201320).

\section{Disclosure Statement}

All authors declare there are no conflicts of interest.

\section{References}

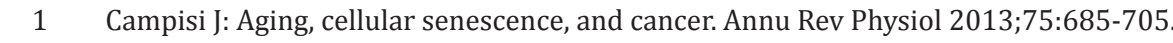

-2 Chimenti C, Kajstura J, Torella D, Urbanek K, Heleniak H, Colussi C, Di Meglio F, Nadal-Ginard B, Frustaci A, Leri A, Maseri A, Anversa P: Senescence and death of primitive cells and myocytes lead to premature cardiac aging and heart failure. Circ Res 2003;93:604-613.

-3 Minamino T, Komuro I: Vascular cell senescence: Contribution to atherosclerosis. Circ Res 2007;100:15-26.

4 Kovacic JC, Moreno P, Hachinski V, Nabel EG, Fuster V: Cellular senescence, vascular disease, and aging: Part 1 of a 2-part review. Circulation 2011;123:1650-1660.

-5 Kovacic JC, Moreno P, Nabel EG, Hachinski V, Fuster V: Cellular senescence, vascular disease, and aging: Part 2 of a 2-part review: Clinical vascular disease in the elderly. Circulation 2011;123:1900-1910.

-6 Lakatta EG, Levy D: Arterial and cardiac aging: Major shareholders in cardiovascular disease enterprises: Part i: Aging arteries: A "set up" for vascular disease. Circulation 2003;107:139-146.

7 Chatzizisis YS, Coskun AU, Jonas M, Edelman ER, Feldman CL, Stone PH: Role of endothelial shear stress in the natural history of coronary atherosclerosis and vascular remodeling: Molecular, cellular, and vascular behavior. J Am Coll Cardiol 2007;49:2379-2393. 


\section{Cellular Physiology and Biochemistry}

Cell Physiol Biochem 2015;35:1151-1166

\begin{tabular}{l|l}
\hline DOI: $10.1159 / 000373940$ & (C) 2015 S. Karger AG, Basel
\end{tabular}

Jin et al.: Gas6 Delays the Senescence Process in VSMCs

8 Wang JC, Bennett M: Aging and atherosclerosis: Mechanisms, functional consequences, and potential therapeutics for cellular senescence. Circ Res 2012;111:245-259.

-9 Lakatta EG: Arterial and cardiac aging: Major shareholders in cardiovascular disease enterprises: Part iii: Cellular and molecular clues to heart and arterial aging. Circulation 2003;107:490-497.

10 Oellerich MF, Potente M: Foxos and sirtuins in vascular growth, maintenance, and aging. Circ Res 2012;110:1238-1251.

11 Collado M, Blasco MA, Serrano M: Cellular senescence in cancer and aging. Cell 2007;130:223-233.

12 van Deursen JM: The role of senescent cells in ageing. Nature 2014;509:439-446.

13 Qiu H, Zhu Y, Sun Z, Trzeciakowski JP, Gansner M, Depre C, Resuello RR, Natividad FF, Hunter WC, Genin GM, Elson EL, Vatner DE, Meininger GA, Vatner SF: Short communication: Vascular smooth muscle cell stiffness as a increased aortic stiffness with aging. Circ Res 2010;107:615-619.

14 Minamino T, Miyauchi H, Yoshida T, Tateno K, Kunieda T, Komuro I: Vascular cell senescence and vascular aging. J Mol Cell Cardiol 2004;36:175-183.

-15 Tchkonia T, Zhu Y, van Deursen J, Campisi J, Kirkland JL: Cellular senescence and the senescent secretory phenotype: Therapeutic opportunities. J Clin Invest 2013;123:966-972.

16 Tahara H, Sato E, Noda A, Ide T: Increase in expression level of p21sdi1/cip1/waf1 with increasing division age in both normal and sv40-transformed human fibroblasts. Oncogene 1995;10:835-840.

17 Levine AJ: P53, the cellular gatekeeper for growth and division. Cell 1997;88:323-331.

18 Serrano M, Lin AW, McCurrach ME, Beach D, Lowe SW: Oncogenic ras provokes premature cell senescence associated with accumulation of p53 and p16ink4a. Cell 1997;88:593-602.

19 Campisi J: Cellular senescence as a tumor-suppressor mechanism. Trends Cell Biol 2001;11:S27-31.

20 Campisi J: Senescent cells, tumor suppression, and organismal aging: Good citizens, bad neighbors. Cell 2005;120:513-522.

-21 Janzen V, Forkert R, Fleming HE, Saito Y, Waring MT, Dombkowski DM, Cheng T, DePinho RA, Sharpless NE, Scadden DT: Stem-cell ageing modified by the cyclin-dependent kinase inhibitor p16ink4a. Nature 2006;443:421-426.

-22 Coppe JP, Rodier F, Patil CK, Freund A, Desprez PY, Campisi J: Tumor suppressor and aging biomarker p16(ink4a) induces cellular senescence without the associated inflammatory secretory phenotype. J Biol Chem 2011;286:36396-36403.

-23 Xue W, Zender L, Miething C, Dickins RA, Hernando E, Krizhanovsky V, Cordon-Cardo C, Lowe SW: Senescence and tumour clearance is triggered by p53 restoration in murine liver carcinomas. Nature 2007;445:656-660.

-24 Baker DJ, Wijshake T, Tchkonia T, LeBrasseur NK, Childs BG, van de Sluis B, Kirkland JL, van Deursen JM: Clearance of p16ink4a-positive senescent cells delays ageing-associated disorders. Nature 2011;479:232236.

-25 Passos JF, Nelson G, Wang C, Richter T, Simillion C, Proctor CJ, Miwa S, Olijslagers S, Hallinan J, Wipat A, Saretzki G, Rudolph KL, Kirkwood TB, von Zglinicki T: Feedback between p21 and reactive oxygen production is necessary for cell senescence. Mol Syst Biol 2010;6:347.

-26 Schneider C, King RM, Philipson L: Genes specifically expressed at growth arrest of mammalian cells. Cell 1988;54:787-793.

27 Janssen JW, Schulz AS, Steenvoorden AC, Schmidberger M, Strehl S, Ambros PF, Bartram CR: A novel putative tyrosine kinase receptor with oncogenic potential. Oncogene 1991;6:2113-2120.

-28 Varnum BC, Young C, Elliott G, Garcia A, Bartley TD, Fridell YW, Hunt RW, Trail G, Clogston C, Toso RJ, Yanagihara D, Bennett L, Sylber M, Merewether LA, Tseng A, Escobar E, Liu D, Yamane HK: Axl receptor tyrosine kinase stimulated by the vitamin k-dependent protein encoded by growth-arrest-specific gene 6 . Nature 1995;373:623-626.

29 Lemke G: Biology of the tam receptors. Cold Spring Harb Perspect Biol 2013;5:a009076.

-30 Melaragno MG, Cavet ME, Yan C, Tai LK, Jin ZG, Haendeler J, Berk BC: Gas6 inhibits apoptosis in vascular smooth muscle: Role of axl kinase and akt. J Mol Cell Cardiol 2004;37:881-887.

- 31 Son BK, Kozaki K, Iijima K, Eto M, Kojima T, Ota H, Senda Y, Maemura K, Nakano T, Akishita M, Ouchi Y: Statins protect human aortic smooth muscle cells from inorganic phosphate-induced calcification by restoring gas6-axl survival pathway. Circ Res 2006;98:1024-1031. 


\section{Cellular Physiology and Biochemistry}

Cell Physiol Biochem 2015;35:1151-1166

\begin{tabular}{l|l}
\hline DOI: $10.1159 / 000373940$ & (C) 2015 S. Karger AG, Basel
\end{tabular}

www.karger.com/cpb

Jin et al.: Gas6 Delays the Senescence Process in VSMCs

32 Hurtado B, Munoz X, Recarte-Pelz P, Garcia N, Luque A, Krupinski J, Sala N, Garcia de Frutos P: Expression of the vitamin $\mathrm{k}$-dependent proteins gas 6 and protein $\mathrm{s}$ and the tam receptor tyrosine kinases in human atherosclerotic carotid plaques. Thromb Haemost 2011;105:873-882.

33 Borgel D, Durand E, Clauser S, Bachelot-Loza C, Peyrard S, Remones V, Aiach M, Lafont A: Plasma gas6 levels and coronary artery disease. Thromb Haemost 2009;101:215-216.

-34 Munoz X, Obach V, Hurtado B, de Frutos PG, Chamorro A, Sala N: Association of specific haplotypes of gas6 gene with stroke. Thromb Haemost 2007;98:406-412.

-35 Munoz X, Sumoy L, Ramirez-Lorca R, Villar J, de Frutos PG, Sala N: Human vitamin k-dependent gas6: Gene structure, allelic variation, and association with stroke. Hum Mutat 2004;23:506-512.

36 Kipling D, Wynford-Thomas D, Jones CJ, Akbar A, Aspinall R, Bacchetti S, Blasco MA, Broccoli D, DePinho RA, Edwards DR, Effros RB, Harley CB, Lansdorp PM, Linskens MH, Prowse KR, Newbold RF, Olovnikov AM, Parkinson EK, Pawelec G, Ponten J, Shall S, Zijlmans M, Faragher RG: Telomere-dependent senescence. Nat Biotechnol 1999;17:313-314.

-37 Sikora E, Arendt T, Bennett M, Narita M: Impact of cellular senescence signature on ageing research. Ageing Res Rev 2011;10:146-152.

-38 Hayflick L, Moorhead PS: The serial cultivation of human diploid cell strains. Exp Cell Res 1961;25:585621.

-39 Lassegue B, Griendling KK: Nadph oxidases: Functions and pathologies in the vasculature. Arterioscler Thromb Vasc Biol 2010;30:653-661.

40 Nguyen Dinh Cat A, Montezano AC, Burger D, Touyz RM: Angiotensin ii, nadph oxidase, and redox signaling in the vasculature. Antioxid Redox Signal 2013;19:1110-1120.

-41 Herbert KE, Mistry Y, Hastings R, Poolman T, Niklason L, Williams B: Angiotensin ii-mediated oxidative DNA damage accelerates cellular senescence in cultured human vascular smooth muscle cells via telomeredependent and independent pathways. Circ Res 2008;102:201-208.

-42 Kunieda T, Minamino T, Nishi J, Tateno K, Oyama T, Katsuno T, Miyauchi H, Orimo M, Okada S, Takamura M, Nagai T, Kaneko S, Komuro I: Angiotensin ii induces premature senescence of vascular smooth muscle cells and accelerates the development of atherosclerosis via a p21-dependent pathway. Circulation 2006;114:953-960.

43 Campisi J, d'Adda di Fagagna F: Cellular senescence: When bad things happen to good cells. Nat Rev Mol Cell Biol 2007;8:729-740.

44 Hong H, Takahashi K, Ichisaka T, Aoi T, Kanagawa O, Nakagawa M, Okita K, Yamanaka S: Suppression of induced pluripotent stem cell generation by the p53-p21 pathway. Nature 2009;460:1132-1135.

45 Takahashi A, Ohtani N, Yamakoshi K, Iida S, Tahara H, Nakayama K, Nakayama KI, Ide T, Saya H, Hara E: Mitogenic signalling and the p16ink4a-rb pathway cooperate to enforce irreversible cellular senescence. Nat Cell Biol 2006;8:1291-1297.

-46 Dimri GP, Lee X, Basile G, Acosta M, Scott G, Roskelley C, Medrano EE, Linskens M, Rubelj I, Pereira-Smith O: A biomarker that identifies senescent human cells in culture and in aging skin in vivo. Proc Natl Acad Sci U S A 1995;92:9363-9367.

47 Korshunov VA, Daul M, Massett MP, Berk BC: Axl mediates vascular remodeling induced by deoxycorticosterone acetate-salt hypertension. Hypertension 2007;50:1057-1062.

-48 Korshunov VA, Mohan AM, Georger MA, Berk BC: Axl, a receptor tyrosine kinase, mediates flow-induced vascular remodeling. Circ Res 2006;98:1446-1452.

49 Ruan GX, Kazlauskas A: Axl is essential for vegf-a-dependent activation of pi3k/akt. EMBO J 2012;31:16921703.

-50 Ruan GX, Kazlauskas A: Lactate engages receptor tyrosine kinases axl, tie2, and vascular endothelial growth factor receptor 2 to activate phosphoinositide 3-kinase/akt and promote angiogenesis. J Biol Chem 2013;288:21161-21172.

51 Holland SJ, Pan A, Franci C, Hu Y, Chang B, Li W, Duan M, Torneros A, Yu J, Heckrodt TJ, Zhang J, Ding P, Apatira A, Chua J, Brandt R, Pine P, Goff D, Singh R, Payan DG, Hitoshi Y: R428, a selective small molecule inhibitor of axl kinase, blocks tumor spread and prolongs survival in models of metastatic breast cancer. Cancer Res 2010;70:1544-1554.

52 Blomen VA, Boonstra J: Cell fate determination during g1 phase progression. Cell Mol Life Sci 2007;64:3084-3104. 


\section{Cellular Physiology and Biochemistry}

Cell Physiol Biochem 2015;35:1151-1166

\begin{tabular}{l|l}
\hline DOI: $10.1159 / 000373940$ & (c) 2015 S. Karger AG, Basel
\end{tabular}

Jin et al.: Gas6 Delays the Senescence Process in VSMCs

53 Rufini A, Tucci P, Celardo I, Melino G: Senescence and aging: The critical roles of p53. Oncogene 2013;32:5129-5143.

54 Liu S, Knapp S, Ahmed AA: The structural basis of pi3k cancer mutations: From mechanism to therapy. Cancer Res 2014;74:641-646.

55 Mammucari C, Schiaffino S, Sandri M: Downstream of akt: Foxo3 and mtor in the regulation of autophagy in skeletal muscle. Autophagy 2008;4:524-526.

56 van der Horst A, Burgering BM: Stressing the role of foxo proteins in lifespan and disease. Nat Rev Mol Cell Biol 2007;8:440-450.

57 Chu IM, Hengst L, Slingerland JM: The cdk inhibitor p27 in human cancer: Prognostic potential and relevance to anticancer therapy. Nat Rev Cancer 2008;8:253-267.

-58 Polyak K, Lee MH, Erdjument-Bromage H, Koff A, Roberts JM, Tempst P, Massague J: Cloning of p27kip1, a cyclin-dependent kinase inhibitor and a potential mediator of extracellular antimitogenic signals. Cell 1994;78:59-66.

-59 Medema RH, Kops GJ, Bos JL, Burgering BM: Afx-like forkhead transcription factors mediate cell-cycle regulation by ras and pkb through p27kip1. Nature 2000;404:782-787.

60 Malek NP, Sundberg H, McGrew S, Nakayama K, Kyriakides TR, Roberts JM: A mouse knock-in model exposes sequential proteolytic pathways that regulate p27kip1 in g1 and s phase. Nature 2001;413:323327.

61 Malumbres M, Barbacid M: Cell cycle, cdks and cancer: A changing paradigm. Nat Rev Cancer 2009;9:153166.

62 Aleem E, Kiyokawa H, Kaldis P: Cdc2-cyclin e complexes regulate the g1/s phase transition. Nat Cell Biol 2005; 7:831-836.

63 Arden KC: Foxos in tumor suppression and stem cell maintenance. Cell 2007;128:235-237.

64 Greer EL, Brunet A: Foxo transcription factors at the interface between longevity and tumor suppression. Oncogene 2005;24:7410-7425.

65 Schmidt M, Fernandez de Mattos S, van der Horst A, Klompmaker R, Kops GJ, Lam EW, Burgering BM, Medema RH: Cell cycle inhibition by foxo forkhead transcription factors involves downregulation of cyclin d. Mol Cell Biol 2002;22:7842-7852.

66 Dharaneeswaran H, Abid MR, Yuan L, Dupuis D, Beeler DL, Spokes K, Janes L, Sciuto T, Kang PM, Jaminet SC, Dvorak A, Grant MA, Regan E, Aird WC: Foxo1-mediated activation of akt plays a critical role in vascular homeostasis. Circ Res 2014;115:238-251. 